\title{
Academic Libraries and Copyright: Do Librarians Really Have the Required Knowledge?
}

\author{
Juan-Carlos Fernández-Molina, João Batista E. \\ Moraes, and José Augusto C. Guimarães
}

\begin{abstract}
A solid professional performance on the part of academic librarians at present calls for adequate knowledge about copyright law, not only for the development of their own tasks without infringing the law, but also to guide and provide pertinent advice for library users (faculty and students). This paper presents the results of an online survey of Brazilian academic librarians, the objective being to determine the level of knowledge about basic questions on copyright related to their professional activities. The case of Brazil is especially relevant, as it is one of the few countries still not including library exceptions and limitations in its copyright law. Our results make manifest important gaps in knowledge about copyright, underlining the need for a training program to remedy the situation. Moreover, because training is needed for current as well as future professionals, it should be implemented in both the professional and the educational sector.
\end{abstract}

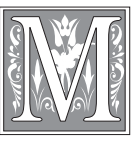

ost informational resources that make up university library collections are copyrighted works, meaning that a good proportion of the everyday activity of these libraries comes into contact with copyright law. We can find a wide array of examples. If one copies, photocopies, scans, or digitizes a work, the right of reproduction must be taken into account, as it does when something is downloaded from the Internet. Making a work available to the public, whether over Internet or in an intranet, has implications for the right of communication to the public (that is, the right to perform or display the work publicly according to U.S. law). If a work is adapted, translated, or summarized, we run into the right of transformation. Moreover, the moral rights of the authors, which were rarely an issue when dealing with analog information, are strongly affected in the case of digital information. ${ }^{1}$ Thus, modifying or eliminating the authorship data of a work is an infraction of the right of paternity/attribution, while significantly altering a work, for instance through activities of digital preservation, may entail an infraction of the right of integrity. Problems can also arise surrounding some norms recently included in most

Juan-Carlos Fernández-Molina is Professor, Department of Information and Communication Studies, University of Granada, Spain; e-mail: jcfernan@ugr.es. João Batista E. Moraes is Associate Professor and José Augusto C. Guimarães is Professor, Department of Information Science, State University of Sao Paulo, Brazil; e-mail:jota@marilia.unesp.br; guima@marilia.unesp.br.@2017 Juan-Carlos Fernández-Molina, João Batista E. Moraes, and José Augusto C. Guimarães, Attribution-NonCommercial (http://creativecommons. org/licenses/by-nc/4.0/) CC BY-NC. 
national copyright laws - the ones intended to safeguard technological measures (for instance, when accessing the contents of a work that is protected by a DRM (Digital Rights Management) system.

Therefore, all these commonplace activities in university libraries can only be carried out without infringing the law if: a) the work is not copyrighted; $b$ ) the activity is carried out by the copyright holder or with his/her permission; or c) the activity can be included in one of the copyright exceptions and limitations. Given the scarce probability of the first two options, for librarians the third one is key-knowing on which occasions and under what circumstances a copyrighted work can be used without requesting permission from the rights holders.

This conflict between the rights of the library and its users on the one hand and the rights of copyright owners on the other hand has become extremely complicated by the development of the digital setting. ${ }^{2}$ Indeed, digital technology has not only radically transformed the means of creating and diffusing intellectual works, it has also had a direct impact on copyright law, which has undergone recent modifications on the international level and in different national laws. In general terms, these legal reforms, together with the new and additional layers of protection provided by DRM systems and licensing agreements, have led to legislation that is more favorable to the interests of the rights holders ${ }^{3}$ and is very hard to understand for nonspecialists. Aside from legislative and technological changes, a series of factors has contributed to an increased complexity specifically in the academic realm. They may be summed up as: a) a greater use of informational resources under license; b) the development of digital repositories in universities; c) an increase in e-learning activities; and d) the copyleft movement.

The first of these stands as a drastic modification of the situation of university library collections. Unlike information in printed format, which was acquired as property by the library, digital resources (such as databases, electronic journals, e-books) are not purchased. Instead, payment is made in exchange for their usage in agreement with the terms and conditions established in a license. This is a huge obstacle, for the libraries and especially the users (professors and students), who need to know what they can or cannot do with each piece of work they consult-every license is different, their contents are not readily understood by the layman, and the contents of the license may not be easy to access.

Meanwhile, digital repositories have been set up by practically all universities to gather the results of research by their members. Their success depends on how well they are used - that is to say, the knowledge that professors and students have about their conditions of use and the legal and practical implications of one's depositing an article or graduate dissertation in the university repository.

Equally relevant is the third of the above four factors, the increase in online teaching activities. The materials and educational resources prepared by faculty or students flow out of the physical space of the classroom or office and end up online to be shared by other members of the academic community, on any campus. Hence, it is essential for academic librarians to be familiar with all the legal implications of professors and students using and diffusing copyrighted works created by other authors, as well as the rights that they themselves hold (having elaborated teaching materials or assignments). ${ }^{4}$

Finally, the new technological developments and the rigidity of current copyright legislation have given rise to a series of movements intended to modify the present legal system. This "copyleft" movement has undertaken initiatives in the academic world such as open access and Creative Commons licenses. A main obstacle for consolidating the former is, precisely, the uncertainty that plagues researchers about what they may and may not do with their scientific articles, what rights are handed over 
to the publishers, and which rights remain, and so forth. ${ }^{5}$ As a result, many academic authors hesitate to file their works in the repositories. In turn, CC licenses extended over into the scientific and educational realm after proving successful in the world of musical and audiovisual production. ${ }^{6}$

Clearly, this is a vast battlefield that does not exclusively involve librarians. Professors and students, as users and creators of intellectual works, are affected by a legislative corpus whose essential contents are largely unknown or misunderstood. The position of the library is therefore a strategic one. Because librarians are able to provide assistance and advice to users, they have adopted a new role as trainers/advisors in copyright issues, ${ }^{7}$ proving particularly useful in fighting against plagiarism. ${ }^{8}$ It thus comes as no surprise that the demand for professionals with this profile has grown in recent years. ${ }^{9}$

This brings us to the all-important question: Do academic librarians have the knowledge necessary to take on such functions? Are they familiar enough with copyright legislation to take advantage of library exceptions and limitations without infringing the law? Do they really know what they may and may not do with a given work, under what conditions and circumstances? And are they truly prepared to act as guides through the thicket of copyright in the academic setting, for professors and students alike?

The present contribution attempts to determine the level of knowledge of Brazilian university librarians regarding basic matters of copyright affecting their everyday activity. The case of Brazil is especially relevant, as it is one of the few countries of the world that still does not include library exceptions and limitations in its copyright law. To this end, we elaborated an online questionnaire, whose results are analyzed and commented upon. To enhance comprehension, in addition to a review of the most pertinent scientific literature, we offer a brief introduction to the basic concepts of copyright legislation and its international regulation, plus an overview of Brazilian copyright legislation, touching on matters of a general nature as well as some aspects more closely related to the library or academic setting. ${ }^{10}$

\section{Literature Review}

Despite its importance, librarians' knowledge about copyright has only been addressed by a few studies thus far. With diverse focuses and methodologies, all the studies to date come to the general conclusion that the knowledge of librarians is insufficient. One of the first such studies was that of Masango, whose empirical survey brought to light erroneous perceptions about the copyright of digital information-not only on the part of librarians, but also of managers of consortia, informed users, and corporate rights holders. ${ }^{11}$ Cross and Edwards made manifest the deficiencies in the training of academic librarians, in this case analyzing curricula and faculty composition at all 57 institutions that offer ALA-accredited graduate degrees. ${ }^{12}$ Charbonneau and Priehs carried out a survey about copyright awareness and training needs among academic librarians that also demonstrated insufficient knowledge and the need for more training in this area. ${ }^{13}$ The study by Olaka \& Adkins in Kenya, based on a survey, focused on the differences in knowledge found among the five different grades of their academic librarians. ${ }^{14}$ Although it was focused exclusively on library deans and directors, the study developed by J. Eye offers interesting results. It is the only such study where those surveyed demonstrate a fairly positive performance, yet the questions were also quite basic; and the participants were apparently aware of this, as only 11 percent of them considered that library schools were providing adequate training in this subject matter. ${ }^{15}$

There are likewise few studies, and reflecting poor results, when the focus is on other members of the university community: professors and students. The pioneer study by Smith et al. among the health science faculty of two U.S. universities (University of Alabama at Birmingham and the University of Texas Health Science Center at San 
Antonio) used a web survey to determine professors' level of knowledge regarding copyright law and fair use. The results made manifest a lack of familiarity with these matters on the part of the professors, along with a noteworthy degree of agreement among respondents from both universities to almost all of the questions. ${ }^{16} \mathrm{~A}$ similarly poor level of knowledge was demonstrated by professors of the University of Granada (Spain). In this case, the survey involved only those who carried out online teaching, considering that they would be more familiar with copyright matters, since their teaching material was imparted following the model of the OpenCourseWare consortium with the corresponding CC license. ${ }^{17}$ The study by M. Sims at the University of Minnesota combined interviews and an online survey to assess the knowledge of professors and librarians about basic matters of copyright related with common academic practices. Again, the findings reflected numerous errors and misconceptions, although the librarians were found to be a step ahead of the professors. ${ }^{18}$

As regards the students, two studies in Taiwan deserve mention, as they brought to light numerous misunderstandings about even the most basic aspects of copyright. ${ }^{19}$ Also negative were the results of a survey of 400 undergraduate students at the University of Extremadura, with very simple questions about copyright and copyleft. ${ }^{20}$ It is remarkable that students from both Taiwan and Spain harbor the erroneous idea that Internet is some sort of "lawless frontier" where one does not have to respect the same norms as in the analog world. Not much better were the results of a study by the Joint Information Systems Committee, in this case, however, involving only doctoral students. ${ }^{21}$ Finally, there is one study that obtained fairly positive results, undertaken by Datig and Russell in the New York University Abu Dhabi. ${ }^{22}$

\section{Copyright Law: An International Overview}

The first modern copyright laws emerged in the 18th century, putting an end to the previous system based on the privileges and monopolies of printers and on the censorship by the Crown. The concession of rights to the authors of intellectual works essentially meant monopolizing the use of works, which contradicted new liberal ideals and therefore called for a legal-philosophical justification. In the countries of the Anglo-Saxon legal system (common law), the reasoning was based on public interest for the promotion of culture, science, and the arts; in contrast, the Latin countries (civil law) upheld the property rights of the author to his/her intellectual creations.

These distinct historical underpinnings of copyright law have practical consequences. Although both systems try to balance the interests of authors and those of society at large, they do so in different ways. The most significant example lies in the moral rights of the authors. Legislation in the civil law countries reflects a greater level of appreciation for the author, recognizing most, or all, of the rights associated with an author's moral rights. In turn, the common law countries only acknowledge some rights, and they do so in a more restrictive manner, with regard both to the duration and the possibility of waiving and transferring those rights. ${ }^{23}$ There are also important differences in the copyright exceptions: while the civil law countries include a list of specific statutory exceptions in their laws, the common law countries establish broad factors (fair use/dealing) that are appraised and applied by courts with substantial flexibility, case by case. The role of organizations or corporations is also different, as they can be qualified as authors in the Anglo-Saxon lands, hence original copyright holders, but in the Latin countries authorship can only attributed to "natural persons." ${ }^{24}$

Given that the copyright laws were only effective within the borders of each country, in the second half of the 19th century the need for an international framework became clear. The first international instrument-signed by 10 European countries-was the Berne Convention (1886), which established a minimum standard regarding subject 
matter and rights protected..$^{25}$ Even though it has since extended throughout the world, currently with 168 contracting parties, there is still no real international norm that binds all countries; the Berne Convention only provides a multilateral overlay. This has changed somewhat in recent years to favor the international dissemination of works of authorship, the number and the impact of the multilateral instruments has increased, giving rise to a greater level of harmonization among national copyright laws. ${ }^{26}$

The most important of these instruments, and the one that does indeed establish a true international "system" for intellectual property protection, is the TRIPs (Trade-Related Aspects of Intellectual Property Rights) accord, included as a part of the agreements on the creation of the World Trade Organization (WTO) in $1994 .{ }^{27}$ Its contents are very similar to the Berne Convention, except that it extends the protection to computer programs and data compilations and does not include moral rights. Its main contribution is that it subsumes the main international copyright obligations within the WTO Dispute Settlement system ${ }^{28}$ so that its provisions on enforcement of copyright are highly relevant. ${ }^{29}$ Shortly thereafter, and in an attempt to adapt to the digital environment, the WIPO Copyright Treaty (1996) ${ }^{30}$ was approved, likewise contributing to the formulation of a minimum international content of copyright subject matter and rights, including new obligations to protect against the circumvention of technological protection measures, and against the removal or tampering with copyright management information. ${ }^{31}$ Finally, it is important to highlight the impact on this process of free trade agreements, whether bilateral or multilateral, promoted by the United States and the European Union, which always include a section dedicated to intellectual property rights. ${ }^{32}$

This harmonization process has helped lessen the differences between national copyright laws, even among countries belonging to one or the other main legal traditions. For instance, in recent years moral rights have been included in the laws of Anglo-Saxon countries such as the United Kingdom, Canada, or Australia, though in the United States they only apply to visual artists. There are also fewer differences these days regarding copyright exceptions: the common law countries include, in addition to the broad fair use or fair dealing factors, specific exceptions aimed at particular uses or users. The civil law countries, meanwhile, have added the "three-step test" after the list of statutory exceptions, which serves as a ceiling for courts and regulators to interpret the specific statutory exceptions. ${ }^{33}$

\section{Brazilian Copyright Law: A Summary}

As in any country pertaining to the civil law system, Brazilian copyright law attaches great importance to moral rights, ${ }^{34}$ which cannot be waived; even those of paternity and integrity are perpetual. This has very significant repercussions when it comes to defining the public domain. In all countries undersigning the Berne Convention, Brazil included, the author does not need to fulfill any formal requisite to obtain the copyright of a work created, as the very fact of creation suffices. With regard to the duration of copyright, Brazil followed the worldwide predominant trend in its 1998 reform, with copyright extended until 70 years after an author's death (as in the European Union and the United States).

Exceptions and limitations are a key element of any copyright law, ensuring a proper balance among all the interests in play. The contents of the Brazilian law are poorly developed and somewhat obsolete. ${ }^{35}$ Some common ones are explicitly addressed: private copying, quotations, news, for the benefit of visually impaired people. But it does not include two of the most relevant ones for the academic setting: illustration for teaching, and library exceptions. Especially meaningful is the latter, an absence underlined in the three reports by Kenneth Crews, in that only a few countries (just 32 out of the 188 analyzed) fail to include exceptions and limitations for libraries. ${ }^{36}$ 
Interestingly enough, however, Brazil's law does address the subject of DRM systems. It was one of the first to do so, the 1988 reform including an article prohibiting the alteration, elimination, modification, or circumvention of technical devices used to restrict the duplication of or public communication of works. Perhaps due to the excessive haste in specifying this regulation, it was incomplete. In contrast to similar laws, it foresees no mechanism to face the conflict between technological protection and the application of copyright exceptions and limitations.

The inadequacy of the Brazilian copyright law is recognized by the Government of Brazil. In 2010 it initiated a process of substantial reform, updating exceptions and limitations, including those that favor libraries. Yet the reformed law has not yet been ratified.

\section{Methodology}

To select the academic libraries to be included in the study, we consulted the Ranking Universitário Folha (RUF) of the year 2014 (http://ruf.folha.uol.com.br/2014/). We chose the universities best situated in this ranking, which is based on various criteria (research, teaching, job market, innovation, internationalization) similar to those of the main international rankings, but adapted to Brazilian reality. We established a score of 85 (out of 100) as the minimum, a cutoff surpassed by the top 17 of the institutional ranking. Two universities (Universidade Federal de Bahia and Universidade Federal de Santa María, respectively ranked 14 and 15) chose not to participate in the study. Therefore, the final list (appendix A) takes in 15 universities.

Having selected the institutions, we proceeded to obtain the e-mail addresses of the librarians, which proved to be no simple task. The information provided on their webpages was not always clear, and it was often difficult to discern library professionals from other staff working in the library as auxiliaries or administrative assistants. For this reason, we sent e-mails to the respective library directors and managers requesting information. Furthermore, to ensure that only the responses by library professionals strictly speaking would be taken into account, we added an item to the questionnaire about whether they held a BA in LIS (in Brazil this degree is necessary for librarians). Altogether, we gathered the data and e-mail addresses of 482 academic librarians through this procedure. They were sent an e-mail explaining the objectives of our study and the means of accessing and responding to the online questionnaire. Survio (http://www.survio.com/br/) was the option of choice in view of its many questionnaire models and the user-friendly interface in the Portuguese language.

In addition to the items focusing on the personal data of the surveyed personnel, the questionnaire (appendix B) contained 14 questions. The first seven items approach general copyright issues; the following four refer more specifically to academic libraries; and the final three items are about copyleft licenses.

Before making the survey available on Survio, it was subjected to a pretest to detect errors or ambiguous areas. The pretest entailed e-mailing a sample of professors, library professionals, and graduate students of the Department of Information Science of the Universidade Estadual Paulista (UNESP). After a successful response to the pretest, e-mails were sent out to the academic librarians and the questionnaire was available for two months, from 18/03 to 16/05/2014. A total of 172 completed surveys were obtained (response rate of $35.68 \%$ ).

\section{Results}

Below we expound and comment upon the results obtained, following the order in which the items were presented on the questionnaire. For the sake of clarity, they are divided into three sections: general knowledge, academic library environment, and copyleft licenses. 


\section{Knowledge of a General Nature}

The first query addresses a basic notion within copyright, especially in the countries of civil law: the dual character-economic and moral-of copyright. A list of six author rights was given, comprising economic and moral rights, and the question was: "Which of the following constitute moral rights?" The results were remarkably poor. Only three of those surveyed got the answer completely right, that moral rights refer to paternity, integrity, and disclosure. As can be seen in table 1, there was some success in identifying the two most important ones, integrity $(75.74 \%)$ and paternity/attribution $(61.54 \%)$, but even this seems insufficient. Indeed, the latter is more of an intuitive matter and should be easier to identify. Surprisingly negative is the case of right of disclosure (deciding if a work is made available to the public for the first time and, if so, in what form and under what terms and conditions), which was only marked by about a fourth of those surveyed. Moreover, 48.52 percent of the participants responded erroneously that the right of communication to the public is a moral right, when in fact it is an economic right. There would seem to be some serious confusion about both rights.

Better results were harvested for one of the simplest questions, the duration of copyright. Nearly three-fourths of those queried answered correctly that the period extends 70 years after the author's death. This is especially positive if we recall that the period of protection was modified and extended fairly recently (1998).

The results regarding the question about public domain were also quite positive, with a clear majority responding correctly (73.26\%); yet 21.51 percent answered that works of the public domain lacked moral and economic rights. This result may be traced to the popular belief that one may do whatever they wish with works in the public domain. As we mentioned earlier, in countries of civil law, including Brazil, the rights of paternity and integrity are perpetual.

\begin{tabular}{|l|c|c|}
\hline \multicolumn{3}{|c|}{ TABLE 1 } \\
\begin{tabular}{|l} 
Copyright can be broken down into moral rights and economic rights. \\
Indicate which of the following constitute moral rights.
\end{tabular} \\
\hline Right & Frequency & Percentage \\
\hline Communication to the public & 82 & 48.52 \\
\hline Distribution & 24 & 14.20 \\
\hline Disclosure & 47 & 27.81 \\
\hline Integrity & 128 & 75.74 \\
\hline Paternity/Attribution & 104 & 61.54 \\
\hline Reproduction & 35 & 20.71 \\
\hline
\end{tabular}

TABLE 2

As the general rule, how long does copyright last?

\begin{tabular}{|l|c|c|}
\hline Duration of copyright & Frequency & Percentage \\
\hline 50 years after the authors' death & 41 & 23.83 \\
\hline 60 years after the authors' death & 5 & 2.91 \\
\hline 70 years after the authors' death & 126 & 73.26 \\
\hline
\end{tabular}




\begin{tabular}{|l|c|c|}
\hline \multicolumn{3}{|c|}{ TABLE 3 } \\
What does 'public domain' mean? \\
\hline & Frequency & Percentage \\
\hline The author has no moral rights, only economic rights & 9 & 5.23 \\
\hline $\begin{array}{l}\text { The author has no economic rights, but maintains some } \\
\text { moral rights }\end{array}$ & 126 & 73.26 \\
\hline The author has no moral or economic rights & 37 & 21.51 \\
\hline
\end{tabular}

Another question of a general nature was about the need (or not) to fulfill some formal requisite to acquire copyright of a work of our own creation. As seen in table 4 , only $22(12.79 \%)$ got this item right. This comes to confirm there is a widespread belief that acquiring copyright calls for some sort of formal requisite. Hardly any of those surveyed found it feasible that a work would have true legal protection without register, legal deposit, or at least a copyright symbol. In fact, just over half (52.91\%) considered that all of the above requisites were necessary. According to Brazilian law, as in all the countries undersigning the Berne Convention (168 at present), no legal procedure or requisite is needed to obtain copyright of one's creation.

\begin{tabular}{|l|c|c|}
\hline \multicolumn{3}{|c|}{ TABLE 4 } \\
What formal requirements must be met to acquire copyright \\
of the work we have created?
\end{tabular}

The development of the digital setting has complicated the distinction between the rights that make up copyright. We therefore held it relevant to determine whether academic librarians actually knew what right comes into play when engaging in the everyday activity of downloading or uploading digital works. The results are given in figures 1 and 2. In the first case, a very substantial percentage of those surveyed (68.42\%) correctly identified downloading a work from the Internet as an act of reproduction. On the contrary, only 26 respondents $(15.12 \%)$ correctly identified the act of making something available to the public as the equivalent of communication to the public. The most frequent response $(54.07 \%)$, while incorrect, was that it corresponded to the right of distribution. No doubt the problem here is confusion between the usual sense and the legal meaning of the word "distribution." In lay terms, distributing matches the activity of sharing something on the Internet to be used by anyone else; but the strictly legal sense is that it only applies to tangible works (for instance, digital works in physical formats such as a CD or DVD), but not when the works are put out on websites. This distinction has very important legal implications, as the right to distribution is subjected to the first-sale doctrine. That is, it ceases to be valid with the first sale of each item; in contrast, the right of communication to the public does not run out, as it is not tied to concrete items. 


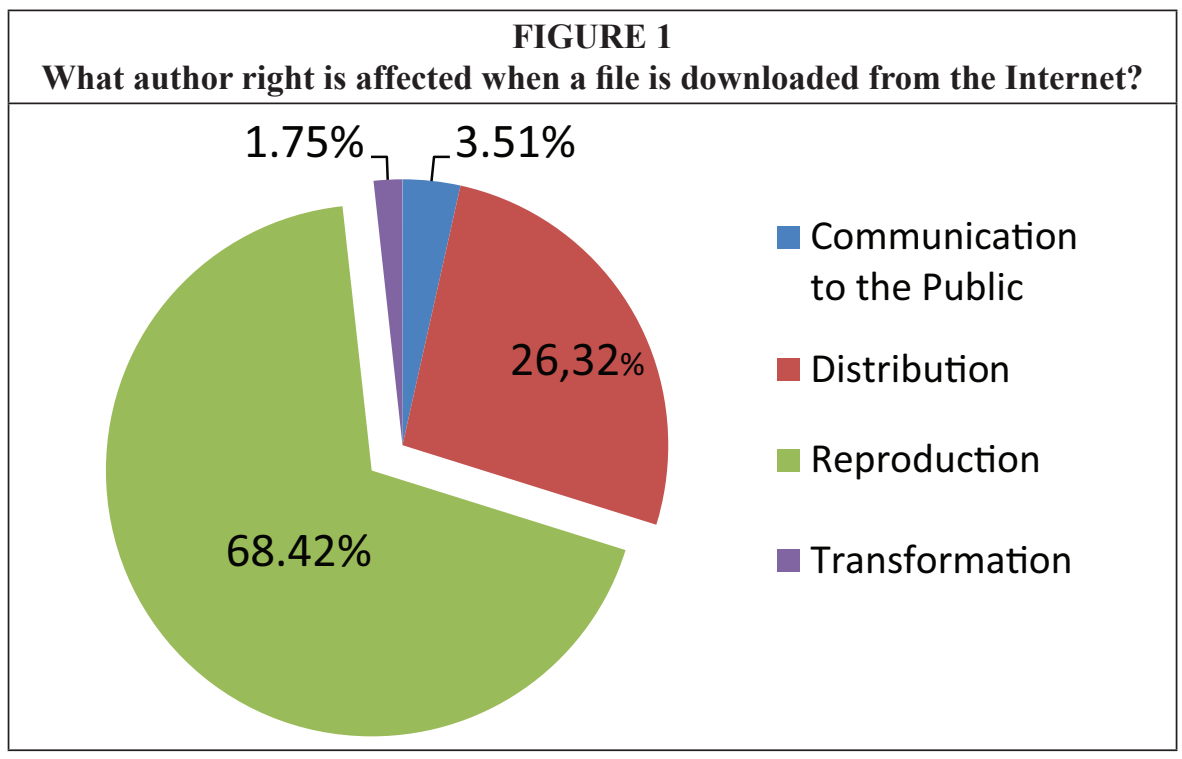

FIGURE 2

What author right is affected when a work is uploaded onto the Internet to be made accessible for anyone?

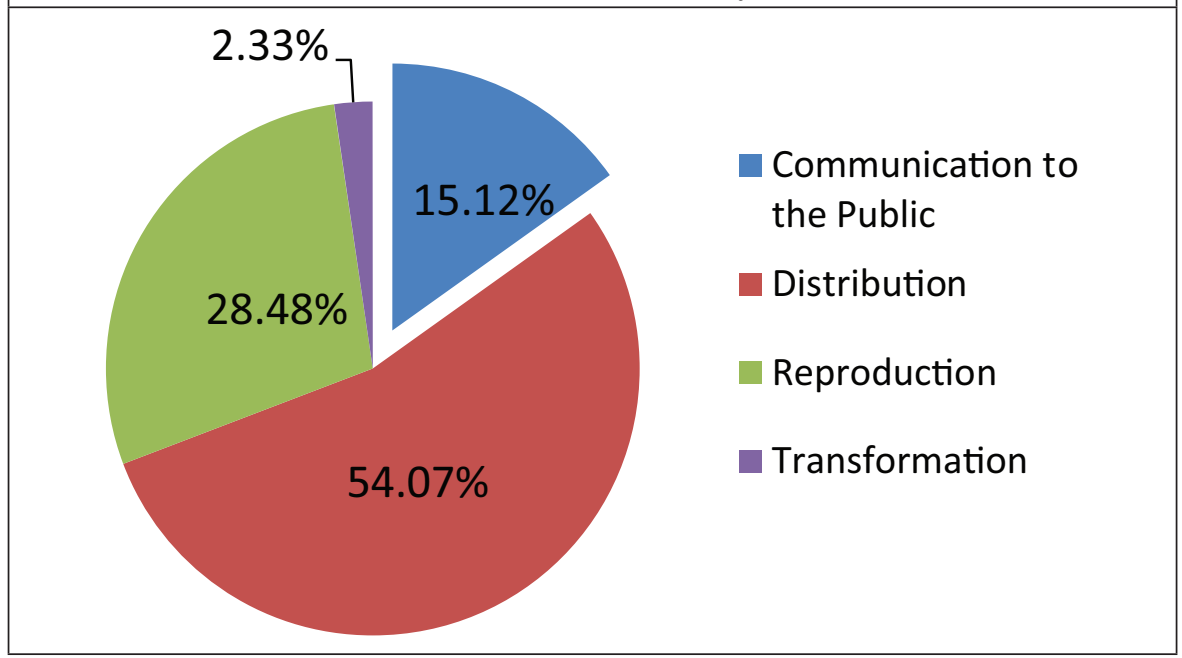

In closing this section on questions of a general nature, we wished to fathom participants' knowledge about copyright exceptions and limitations, but with a very basic query about which ones are included under Brazilian copyright legislation, without getting into more complex matters such as their contents and conditions for application.

The results, shown in table 5, are quite surprising. The exception mentioned most frequently by the respondents, "illustration for teaching," is precisely one NOT included in the Brazilian law. Similar percentages were obtained for two options that are correct, "quotations" and "private copying." For the former, our expectations were high, as quotations are essential in the academic world. For 


\begin{tabular}{|l|c|c|}
\hline \multicolumn{3}{|c|}{ TABLE 5 } \\
Copyright is subjected to certain exceptions and limitations. \\
Indicate which ones are included in the Brazilian copyright law. \\
More than one item may be marked.
\end{tabular}

private copying, we had likewise anticipated good results: it is probably the best known exception, as it affects all people. More logical is the percentage of correct responses regarding the exception in benefit of persons with a disability. Deserving mention here is the exception for libraries, as over 20 percent of respondents mistakenly believed it to be included under the law. Given that everyday activity of academic librarians involves problems related with these rights, such a poor result is clearly unacceptable.

\section{Specific Knowledge in the Academic Library Environment}

The first two questions in this section, on library exceptions, were included even though they are not addressed by Brazilian copyright law. Yet they serve to complement the previous query about exceptions and limitations in general, and the results would point us toward the priorities of an academic library. Thus, the first item was about the aim of preservation, and the second about research and private study, with respective results shown in figures 3 and 4 .

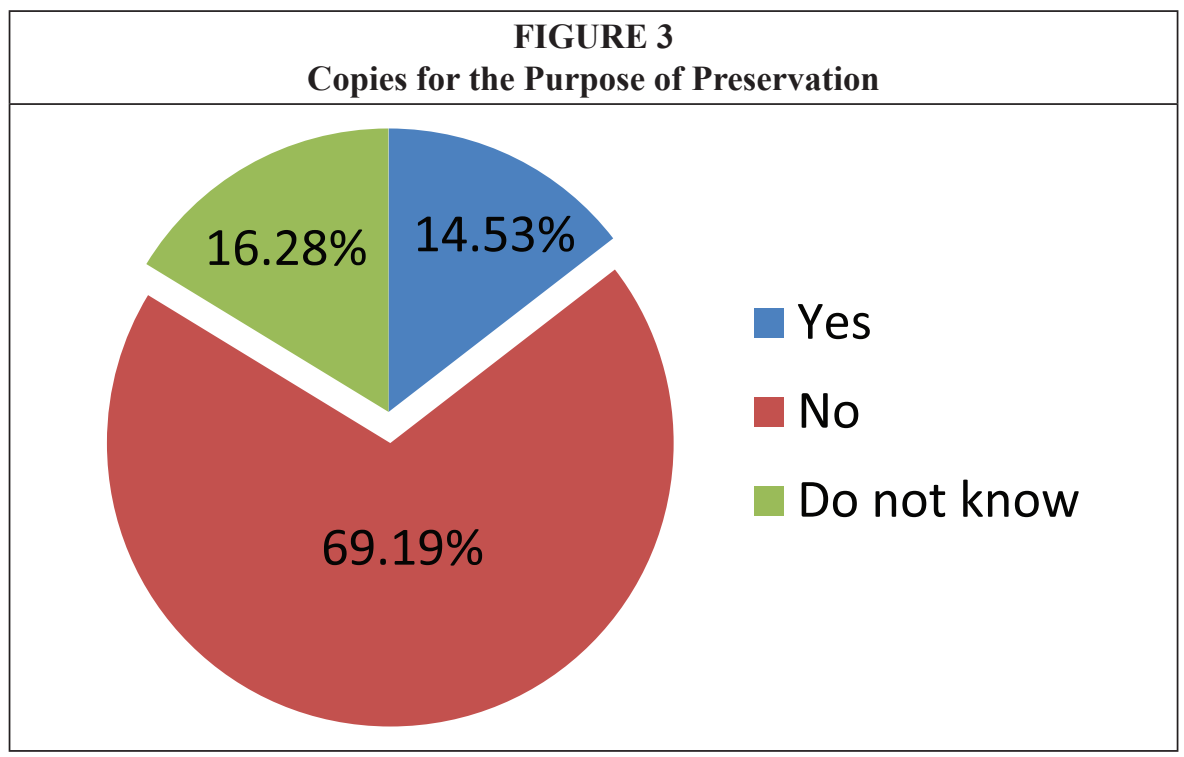




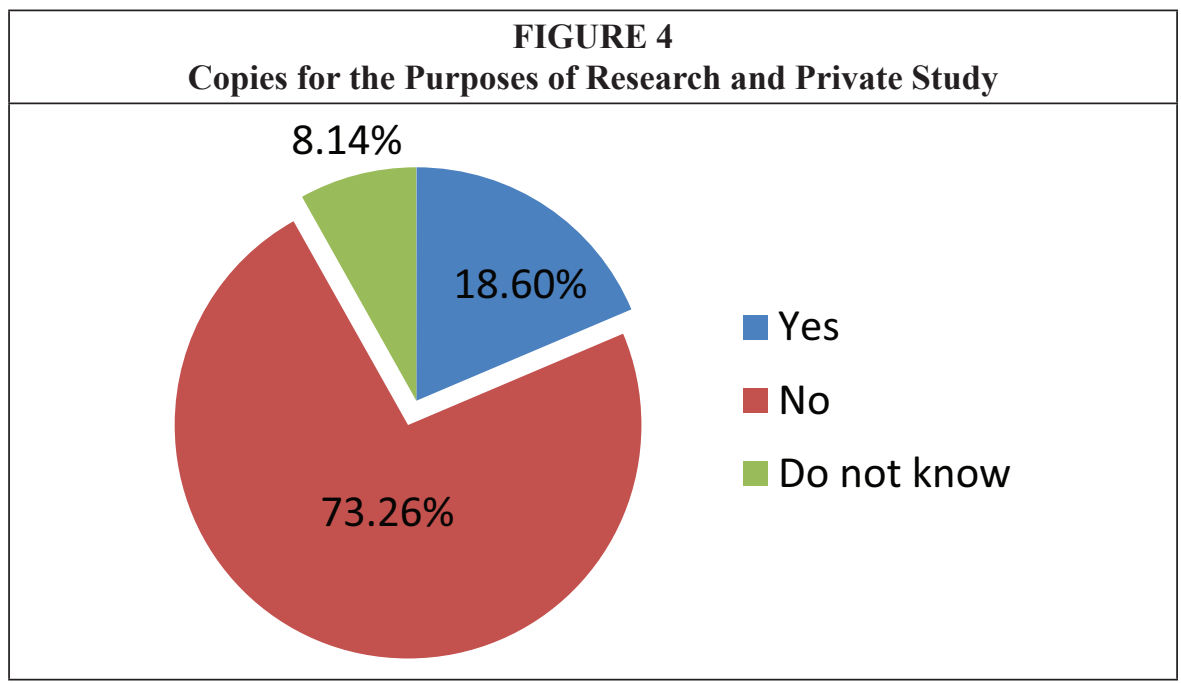

To avoid any uncertainty or ambiguity, the wording of the first question of this section was very specific. It was made clear that no authorization was requested from the rights holder, nor did he/she receive payment for any copies made for the purpose of preservation. In this case, most respondents $(69.19 \%)$ were right, that the law does not allow it, although nearly 15 percent responded incorrectly that it was permitted, and a considerable percentage (16.28\%) said they did not know. The results for the following question were similar. Also with regard to copying, but in this case specifying the objectives of research and private study, 18.60 percent responded incorrectly, and a smaller proportion admitted that they did not know. Altogether, these findings give the impression that the aim of protecting research and private study is considered to be more important than that of preservation.

The other two questions of this section were dedicated to two factors of great influence in recent years: 1 ) the technological protection of works by means of DRM systems, and 2) contractual protection by licenses. With respect to the legal protection that the new laws provide to DRM systems, as reflected in table 6, the library community appears to be well informed. Nearly all respondents $(92.40 \%)$ answered correctly that these systems cannot be circumvented, not even if it is to provide service to users. Just one person answered that it was possible, whereas 13 admitted they did not know.

\section{TABLE 6}

If a digital work acquired by the library has an anti-copy or anti-access device (DRM systems), can this protection be circumvented to make copies for users?

\begin{tabular}{|l|c|c|}
\hline & Frequency & Percentage \\
\hline Yes & 1 & 0.58 \\
\hline No & 158 & 91.86 \\
\hline Do not know & 13 & 7.56 \\
\hline
\end{tabular}

Owing to the great rise in electronic resources available in any university library, it was also important to find out if librarians are aware of significant changes in the conditions of use of works. To this end, we asked whether works could be used with total freedom or if some sort of restriction applied. At one point, we wondered about 
the utility of such a query, surmising that all librarians would surely know that licensing agreements regulate de facto what can and cannot be done with a given work. To our surprise, however, the question was quite revealing. Although the majority $(74.42 \%)$ responded correctly, a considerable percentage incorrectly answered "no" (18.60\%), or that they did not know $(6.98 \%)$.

\begin{tabular}{|l|c|c|}
\hline \multicolumn{3}{|c|}{ TABLE 7} \\
$\begin{array}{c}\text { Do restrictions exist for the use of electronic resources (journals, databases, } \\
\text { ebooks) contracted by the library, or may they be used freely by users? }\end{array}$ \\
\hline & Frequency & Percentage \\
\hline Yes & 128 & 74.42 \\
\hline No & 32 & 18.60 \\
\hline Do not know & 12 & 6.98 \\
\hline
\end{tabular}

\section{Specific Knowledge about Copyleft Licenses}

Finally, in view of the development of copyleft-type licenses, and in particular Creative Commons, so appropriate for the university setting, we angled for some feedback about them. Our queries were basic, first gauging the level of knowledge with respect to their essential contents, and then asking complementary questions about how to take advantage of their widespread availability on the Internet and know how to edit one's own works under this type of license. As shown in table 8, just over half of those surveyed answered correctly that the essence lies in the authors' deciding which rights they retain and which ones they renounce. In one-third of Brazil's academic librarians, the idea prevails that all economic rights are given up, while moral rights are retained. Nevertheless, it is quite common for authors using these licenses to not permit derivative works, meaning that they maintain one of their economic rights, the right of transformation.

\begin{tabular}{|l|c|c|}
\hline \multicolumn{3}{|c|}{ TABLE 8 } \\
\hline \multicolumn{2}{|c|}{ What are Copyleft Licenses? } \\
\hline The author renounces all his/her rights & Frequency & Percentage \\
\hline $\begin{array}{l}\text { The author renounces all economic rights, but not the moral } \\
\text { rights }\end{array}$ & 16 & 9.31 \\
\hline $\begin{array}{l}\text { The author decides which rights are renounced and which are } \\
\text { maintained }\end{array}$ & 95 & 31.39 \\
\hline No answer & 7 & 45.23 \\
\hline
\end{tabular}

Much more disappointing were the responses to two questions about how to take advantage of the CC licenses. More than half (57.65\%) said they did not know how to access such contents, while an even greater percentage $(71.01 \%)$ acknowledged they were incapable of publishing a document with a CC license. This accents a very noteworthy gap in knowledge if we bear in mind that CC licenses are an essential part of the open access and open educational resource (OER) movements, of enormous relevance in today's academic world, and furthermore an area where libraries play a key role. 


\section{Discussion}

Except regarding the duration of copyright and the concept of public domain, Brazil's academic librarians demonstrate very limited knowledge about the most basic matters surrounding copyright. For the most part, they confuse moral rights and economic ones and ignore that it is not necessary to fulfill any formal requisites to acquire the copyright of a created work. Of particular relevance is the confusion between the right of distribution and the right of communication to the public, made manifest again when the query was about uploading a work from the Internet. Likewise, the level of knowledge about exceptions and limitations, a crucial element of copyright law, is unacceptable: many of those surveyed do not know for certain that there are no exceptions in favor of libraries under its national law.

These serious gaps in knowledge are reconfirmed in the first two items in the second section of our questionnaire, about the academic library environment. Between 25 and 30 percent of those surveyed are unaware that libraries absolutely may not make reproductions of works without explicit authorization by the rights holder, not even for purposes of research or private study by the users, or for the purpose of preservation. In contrast, it is very remarkable that more than 90 percent are certain it is not possible to circumvent the technological protection afforded by DRM systems. That is, there is substantial asymmetry in the body of knowledge of academic librarians in Brazil. Why are they unsure about library exceptions, but so certain about technological protection/ circumvention? They also tread firmly on the terrain underlying licenses restricting the allowed uses of digital works that the library has paid for.

The acceptable level of knowledge about the most recent means - technological and contractual-of protecting intellectual works suggests that the basic and classic concepts of copyright are not understood, but the most recent trends and modifications sound familiar. Then again, this premise falls apart when we look at the poor results harvested for copyleft. Even though the questions were very simple (not even asking about differences among types of licenses), a very meager percentage affirmed knowing how to license a work or how to find works with CC licenses. Without some firm grasp of these basic stepping stones, one is unlikely to satisfactorily participate in such important campus initiatives as open educational resources and digital repositories.

The gaps in knowledge outlined above stand as an impediment for the academic librarian who aspires to take on an advisory role in matters of intellectual property, orienting students and professors. But it is also a hindrance for the development of information literacy, as an essential part revolves precisely around the ethical and legal issues of information (standard five and third frame of ACRL standards/framework, respectively). ${ }^{37}$

Even though Brazil has no library exceptions to benefit from, a good knowledge of the law would allow users to take better advantage of the limited options offered. Furthermore, it would lead to a greater awareness with which to fight for modification of the current national law. The advocacy movement should insist on the introduction of library exceptions suited to the needs of the country and its library system. It is very noteworthy that, in the context of the 2010 public consultation (www.cultura.gov.br/ consultadireitoautoral) to modify the law, the most interesting proposals about the inclusion and the contents of library exceptions did not come from the representatives of the professional librarian association, who apparently stood to the side in silence. The voices and ideas came, instead, from an institution dedicated to the study of the impact of technology in society: the Centro de Tecnología e Sociedade de la Fundação Getulio Vargas.

It is impossible to adequately develop a significant part of the tasks of academic librarians in the absence of proper knowledge or training about the ethical and legal issues of information, and very especially copyright law. To this end, it is crucial to 
come up with a training program that will correct this instructional deficit, and the contents should include basic concepts as well as issues arising specifically in the academic library setting. Not to be neglected are the copyleft movements, growing powerful in the academic realm. Training should be directed at active professionals as well as the future staff, LIS students. In other words, updated knowledge should be welcomed by the professional sector as well as the educational sector. In Brazil, the first initiative falls to the professional associations (Conselhos de Biblioteconomia) at the federal and at the state level, since they are in charge of accreditation of the country's librarians. As for the university setting, core contents of curricular plans should include a section on copyright, to be imparted in Bachelor degree studies in Library and Information Science. Such an initiative would logically depend upon the leadership of the Associação Brasileira de Educação em Ciência da Informação-ABECIN (Brazilian Association of LIS Education).

\section{Conclusions}

Although this study is focused on Brazil, the findings expounded here could be extrapolated to most countries worldwide, as there is a generalized problem regarding copyright legislation and the new challenges faced by academic librarians. On the one hand, the process of international harmonization of copyright laws has intensified, with adaptation to the WCT Treaty (1996) by 93 contracting parties at present, and a growing impact of free trade agreements. Accordingly, the contents of national copyright laws and their implications for libraries and the academic realm are similar, at least in the essential aspects. At the same time, developments in the digital setting have led to a more homogeneous array of activities and services provided by academic librarians: they assist professors and researchers in their problems involving scholarly communication - with considerable involvement in the open access movement-and collaborate in the development of e-learning activities. Such activities are increasingly linked to digital resources, whose access is contracted through licensing agreements.

Obviously there are some differences from one country to the next, but the general reality is that training about copyright was far from a priority in the education of today's academic librarians. This subject matter is rarely included or addressed in depth in the study programs of LIS schools. Hence, not many professionals have adequate training - not even in the United States, a pioneer in the development of the new professional role of "copyright officer/librarian" or "scholarly communication officer/librarian." The fact is that such positions are most often taken on by professionals who become experts in the area on their own, due to a combination of experience, knowledge, and curiosity, not by means of specific training designed to provide the knowledge required. ${ }^{38}$

The ultimate aim of training, whether in the academic setting or beyond, is to provide librarians with overall knowledge (not just familiarity) that will guide them through present and future initiatives at their work institutions, allowing them to take advantage of the law to achieve professional objectives. Such a level of knowledge would help librarians overcome the "defensive" attitude that stems from uncertainty about what they legally may or may not do. It would foment a positive approach, eventually transmitted to users, professors, and students, about all the guidelines, advice, and information related to copyright.

\section{Acknowledgement}

This study was supported by the Spanish Ministry of Economy and Competition (Project DER2014-53012-C2-2-R). 


\section{Appendix A. List of Universities with Their Position in RUF Ranking}

\begin{tabular}{|l|l|}
\hline 1 st & Universidade de São Paulo (USP) \\
\hline 2nd & Universidade Federal de Minas Gerais (UFMG) \\
\hline 3rd & Universidade Federal do Rio de Janeiro (UFRJ) \\
\hline 4th & Universidade Federal do Rio Grande do Sul (UFRGS) \\
\hline 5 th & Universidade Estadual de Campinas (UNICAMP) \\
\hline 6th & Universidade Estadual Paulista Júlio de Mesquita Filho (UNESP) \\
\hline 7 th & Universidade Federal de Santa Catarina (UFSC) \\
\hline 8th & Universidade de Brasília (UNB) \\
\hline 9th & Universidade Federal do Paraná (UFPR) \\
\hline 10 th & Universidade Federal de São Carlos (UFSCAR) \\
\hline 11th & Universidade Federal de Pernambuco (UFPE) \\
\hline 12th & Universidade Federal de São Paulo (UNIFESP) \\
\hline 13th & Universidade Federal do Ceará (UFC) \\
\hline 16th & Universidade Federal Fluminense (UFF) \\
\hline 17th & Universidade do Estado do Rio de Janeiro (UERJ) \\
\hline
\end{tabular}

\section{Appendix B. Survey Questions}

\section{A. Knowledge of a General Nature}

1. Copyright can be broken down into moral rights and economic rights. Indicate which of the following constitute moral rights. More than one item may be marked.

- Communication to the public

- Distribution

— Disclosure

- Integrity

- Paternity/attribution

- Reproduction

2. As the general rule, how long does copyright last?

o 50 years after the author's death

o 60 years after the author's death

o 70 years after the author's death

3. What does "public domain" mean?

o There are no moral rights, only economic rights

o There are no economic rights, but some moral rights are maintained

o The author holds no rights, moral or economic

4. What formal requirements must be met to acquire the copyright of a work we have created? 
o Inscription in the register of intellectual property

o Inclusion of copyright symbol

o Making legal deposit

o All three of the above

o No formal requirement is necessary

5. Which author right is affected when an Internet file is downloaded?

- Communication to the public

— Distribution

- Reproduction

_ Transformation

6. Which author right is affected when a work is uploaded to make it accessible for all on the Internet?

- Communication to the public

- Distribution

- Reproduction

— Transformation

7. Copyright is subjected to certain exceptions and limitations. Indicate which ones are included in the Brazilian copyright law. More than one item may be marked.

- Private copying

_ For the benefit of persons with a disability

- Quotations

_ Illustration for instruction

_ For the benefit of libraries and archives

\section{B. Specific Knowledge in the Academic Library Setting}

8. According to the copyright law of Brazil, is it permitted (without authorization or payment for the copyright holder) for libraries to make copies of works in their collections for the purpose of preservation?

o Yes

o No

o Do not know

9. And for the purpose of research and study by users?
o Yes
o No
o Do not know

10. If a digital work acquired by the library has an anticopy or anti-access system (DRM systems), can this protection be circumvented to make copies for users?
o Yes
o No
o Do not know

11. Are there restrictions for the use of electronic resources (journals, databases, e-books) contracted by the library, or can they be used with total freedom by users? 

o Yes
o $\mathrm{No}$
o Do not know

\section{Knowledge on Copyleft Licenses}

12. What are "copyleft" licenses?

o The author renounces all his/her rights

o The author renounces all economic rights but not the moral rights

o The author decides which rights are renounced and which are maintained

13. Would you know how to search for "copyleft" works (Creative Commons and the like)?

o Yes

o No

14. Would you know how to publish a document of your own under a Creative Commons license?

o Yes

o No

\section{Notes}

1. Charles Oppenheim, "Moral Rights and the Electronic Library," Ariadne 4 (1996), available online at www.ariadne.ac.uk/issue4/copyright [accessed 25 September 2015]; Mike Holderness, "Moral Rights and Authors' Rights: The Keys to the Information Age," Journal of Information, Law and Technology 1 (1998), available online at http://elj.warwick.ac.uk/jilt/infosoc/98_1hold/default. htm [accessed 25 September 2015]; J. Carlos Fernández-Molina and Eduardo Peis, "The Moral Rights of Authors in the Age of Digital Information," Journal of the American Society for Information Science and Technology 52, no. 2 (2001): 109-17.

2. Donna L. Ferullo, "Major Copyright Issues in Academic Libraries," Journal of Library Administration 40, no. $1 / 2$ (2004): $23-40$.

3. J. Carlos Fernández-Molina, "Contractual and Technological Approaches for Protecting Digital Works: Their Relationship with Copyright Limitations," Online Information Review 28, no. 2 (2004): 148-57; Kristin R. Eschenfelder, "Every Library's Nightmare? Digital Rights Management, Use Restrictions, and Licensed Scholarly Digital Resources," College \& Research Libraries 69, no. 3 (2008): 205-25.

4. Jackie Alsaffar, "Copyright Concerns in Online Education: What Students Need to Know," Journal of Library Administration 45, no. 1 (2006): 1-16 ; Margaret Wallace, "An Investigation into Copyright Concerns as a Barrier to the Widespread Development of E-learning Practice within Scottish Further Education Colleges," Information \& Communications Technology Law 15, no. 1 (2006): 79-119; Renee Hobbs, Peter Jaszi, and Pat Haufderheide, The Cost of Copyright Confusion for Media Literacy (Washington, D.C.: The Center for Social Media, 2007), available online at http://files.eric. ed.gov/fulltext/ED499465.pdf [accessed 25 September 2015].

5. Elizabeth Gadd, Charles Oppenheim, and Steve Probets, "RoMEO Studies 1: The Impact of Copyright Ownership on Academic Author Self-Archiving," Journal of Documentation 59, no. 3 (2003): 243-77; John Ober, "Facilitating Open Access: Developing Support for Author Control of Copyright," College \& Research Libraries News 67, no. 4 (2006): 219-55; David Forest, "Open Access and Scientific Publishing: The Obstacle of Law?" Documentaliste - Sciences De l'Information 50, no. 4 (2013): 21.

6. Cushla Kapitzke, "Rethinking Copyrights for the Library through Creative Commons Licensing," Library Trends 58, no. 1 (2009): 95-108.

7. Suzanne Araas Vesely, "Do You Need a Copyright Librarian?" Internet Reference Services Quarterly 11, no. 4 (2007): 69-82; Jennifer S. Prilliman, Incorporating the Fifth Standard of ACRL's Information Literacy Competency Standards for Higher Education into Information Literacy Curriculum (Mar. 29, 2012), available online at http://ssrn.com/abstract=2030958 [accessed 25 September 2015]; Rebecca S. Albitz, "Copyright Information Management and the University Library: Staffing, Organizational Placement and Authority," Journal of Academic Librarianship 39, no. 5 (2013): 429-35; Jennifer Duncan, Susanne Clement, and Betty Rozum, “Teaching Our Faculty: Developing 
Copyright and Scholarly Communication Outreach Programs," in Common Ground at the Nexus of Information Literacy and Scholarly Communication, eds. Stephanie Davis-Kahl and Merinda Kaye Hensley (Chicago, Ill.: Association of College and Research Libraries, 2013), 269-85, available online at www.ala.org/acrl/sites/ala.org.acrl/files/content/publications/booksanddigitalresources/ digital/commonground_oa.pdf [accessed 25 September 2015]; Janice M. Jaguszewski and Karen Williams, New Roles for New Times: Transforming Liaison Roles in Research Libraries (Washington, D.C.: Association of Research Libraries, 2013); Corilee Christou, "What If You Gave a Copyright Workshop and No One Came?" Information Today 31, no. 7 (2014): 1.

8. Pamela A. Jackson, "Plagiarism Instruction Online: Assessing Undergraduate Students' Ability to Avoid Plagiarism," College \& Research Libraries 67, no. 5 (2006): 418-28; Lynn D. Lampert, Combating Student Plagiarism: An Academic Librarian's Guide (Oxford: Chandos Publishing, 2008); George P. Germek, "Imagine No Possessions: Librarians, the Net-Generation Student, and the Imminent Victory of Plagiarism," College \& Undergraduate Libraries 16, no. 4 (2009): 338-57; Susan Sciammarella, "Making a Difference: Library and Teaching Faculty Working Together to Develop Strategies in Dealing with Student Plagiarism," Community \& Junior College Libraries 15, no. 1 (2009): 23-34; Yu-Hui Chen and Mary K. Van Ullen, "Helping International Students Succeed Academically through Research Process and Plagiarism Workshops," College \& Research Libraries 72, no. 3 (2011): 209-35; Nancy Snyder Gibson and Christina Chester-Fangman, “The Librarian's Role in Combating Plagiarism," Reference Services Review 39, no. 1 (2011): 132-50; Sarah George, Anne Costigan, and Maria O'Hara, "Placing the Library at the Heart of Plagiarism Prevention: The University of Bradford Experience," New Review of Academic Librarianship 19, no. 2 (2013): 141-60; Carla S. Myers, "Answering Copyright Questions at the Reference Desk: A Guide for Academic Librarians," Reference Librarian 55, no. 1 (2014): 49-73; Connie Strittmatter and Virginia K. Bratton, "Plagiarism Awareness among Students: Assessing Integration of Ethics Theory into Library Instruction," College \& Research Libraries 75, no. 5 (2014): 736-52.

9. Dick Kawooya, Amber Veverka, and Tomas Lipinski, "The Copyright Librarian: A Study of Advertising Trends for the Period 2006-2013," Journal of Academic Librarianship 41, no. 3 (2015): $341-49$.

10. Brazil, Lei nº 9.610, de 19 de fevereiro de 1998. Altera, Atualiza e Consolida a Legislação sobre Direitos Autorais e dá outras Providencias, available online at www.planalto.gov.br/ccivil_03/leis/ L9610.htm [accessed 25 September 2015].

11. Charles A. Masango, "Perceptions about Copyright of Digital Content and Its Effects on Scholarship: A South African Perspective," Libri 57, no. 1 (2007): 84-91.

12. William M. Cross and Phillip M. Edwards, "Preservice Legal Education for Academic Librarians within ALA-Accredited Degree Programs," portal: Libraries and the Academy 11, no. 1 (2011): 533-50.

13. Deborah H. Charbonneau and Michael Priehs, "Copyright Awareness, Partnerships, and Training Issues in Academic Libraries," Journal of Academic Librarianship 40, no. 3/4 (2014): 228-33.

14. Musa Wakhungu Olaka and Denice Adkins, "Exploring Copyright Knowledge in Relation to Experience and Education Level among Academic Librarians in Kenya," International Information and Library Review 44, no. 1 (2012): 40-51.

15. John Eye, "Knowledge Level of Library Deans and Directors in Copyright Law," Journal of Librarianship and Scholarly Communication 2, no. 1 (2013): eP1103, available online at http://dx.doi. org/10.7710/2162-3309.1103 [accessed 2 February 2016].

16. Kay Hogan Smith, Rajia C. Tobia, T. Scott Plutchak, Lynda M. Howell, Sondra J. Pfeiffer, and Michael S. Fitts, "Copyright Knowledge of Faculty at Two Academic Health Science Campuses: Results of a Survey," Serials Review 32, no. 2 (2006): 59-67.

17. J. Carlos Fernández-Molina, E. Muriel, J. Vives-Gracia, P. Riera, and O. Martin, “Copyright and e-Learning: Professors' Level of Knowledge About the New Spanish Law," Aslib Proceedings: New Information Perspectives 63, no. 4 (2011): 340-53.

18. Nancy Sims, "Lies, Damned Lies, and Copyright (Mis)Information: Empowering Faculty by Addressing Key Points of Confusion," in ACRL 2011 Conference (2011): 282-96, available online at www.ala.org/ala/mgrps/divs/acrl/events/national/2011/papers/lies_damned_lies.pdf [accessed 2 February 2016].

19. Chien Chou, Pei-Shan Chan, and Huan-Chueh Wu, "Using a Two-Tier Test to Assess Students' Understanding and Alternative Conceptions of Cyber Copyright Laws," British Journal of Educational Technology 38, no. 6 (2007): 1072-84; Huan-Chueh Wu, Chien Chou, Hao-Ren Ke, and Mei-Hung Wang, "College Students' Misunderstandings about Copyright Laws for Digital Library Resources," Electronic Library 30, no. 2 (2010): 197-209.

20. Enrique Muriel-Torrado and Juan-Carlos Fernández-Molina, "Creation and Use of Intellectual Works in the Academic Environment: Students' Knowledge about Copyright and Copyleft," Journal of Academic Librarianship 41, no. 4 (2015): 441-48.

21. Joint Information Systems Committee, Researchers of Tomorrow: The Research Behaviour of 
Generation Y Doctoral Students (London: JISC /British Library, 2012), available online at www. jisc.ac.uk/media/documents/publications/reports/2012/researchers-of-tomorrow.pdf [accessed 5 January 2016].

22. Ilka Datig and Beth Russell, "“The Fruits of Intellectual Labor': International Student Views of Intellectual Property," College E Research Libraries 76, no. 6 (2015): 811-30.

23. Elizabeth Adeney, The Moral Rights of Authors and Performers: An International and Comparative Analysis (Oxford: Oxford University Press, 2006); Robert Platt, "A Comparative Survey of Moral Rights," Journal of the Copyright Society of the U.S.A. 57, no. 4 (2010): 951-85.

24. Sam Ricketson, "People or Machines: The Berne Convention and the Changing Concept of Authorship," Columbia-VLA Journal of Law E the Arts 16, no. 1 (1991): 1-37; Jane C. Ginsburg, “The Concept of Authorship in Comparative Copyright Law," DePaul Law Review 52, no. 4 (2003): 1063-92, available online at http://via.library.depaul.edu/law-review/vol52/iss4/3 [accessed 5 January 2016].

25. World Intellectual Property Organization, Berne Convention for the Protection of Literary and Artistic Works (as amended on September 28, 1979), available online at www.wipo.int/wipolex/ en/treaties/text.jsp?file_id=283693 [accessed 25 September 2015].

26. Jane C. Ginsburg, "International Copyright: from a 'Bundle' of National Copyright Laws to a Supranational Code?" Journal of the Copyright Society of the U.S.A. 47, no. 1 (2000): 265-89.

27. World Trade Organization, Agreement on Trade-Related Aspects of Intellectual Property Rights, available online at: https://www.wto.org/english/docs_e/legal_e/27-trips.pdf [accessed 5 January 2016].

28. Graeme B. Dinwoodie, "The Development and Incorporation of International Norms in the Formation of Copyright Law," Ohio State Law Journal 62, no. 2 (2001): 733-82.

29. Axel Nordemann, "Berne and Beyond: Understanding International Conventions Relating to Copyright Law," Journal of the Copyright Society of the U.S.A. 59, no. 2 (2012): 263-90.

30. World Intellectual Property Organization, WIPO Copyright Treaty (adopted in Geneva on December 20, 1996), available online at www.wipo.int/treaties/en/text.jsp?file_id=295166 [accessed 5 January 2016].

31. Thomas Vinje, "The New WIPO Copyright Treaty: a Happy Result in Geneva," European Intellectual Property Review 19, no. 5 (1997): 230-36.

32. Jane C. Ginsburg and Edouard Treppoz, International Copyright Law: U.S. and E.U. Perspectives: Text and Cases (Cheltenham, U.K.: Edward Elgar, 2015).

33. Eric J. Schwartz, "An Overview of the International Treatment of Exceptions," Journal of the Copyright Society of the U.S.A. 57, no. 3 (2010): 473-97.

34. Carlos Rogel Vide and Víctor Drummond, Manual de Direito Autoral (Rio de Janeiro: Lumen Juris, 2010).

35. Carlos Alberto Bittar, Direito de Autor, 3rd ed. (Rio de Janeiro: Forense Universitária, 2000).

36. Kenneth Crews, Study on Copyright Limitations and Exceptions for Libraries and Archives (World Intellectual Property Organization, 2008), available online at www.wipo.int/edocs/mdocs/copyright/en/sccr_17/sccr_17_2.pdf [accessed 25 September 2015]; Kenneth Crews, Study on Copyright Limitations and Exceptions for Libraries and Archives (World Intellectual Property Organization, 2014), available online at www.wipo.int/edocs/mdocs/copyright/en/sccr_29/sccr_29_3.pdf [accessed 25 September 2015]; Kenneth D. Crews, Study on Copyright Limitations and Exceptions for Libraries and Archives: Updated and Revised (World Intellectual Property Organization, 2015), available online at www.wipo.int/edocs/mdocs/copyright/en/sccr_30/sccr_30_3.pdf [accessed 25 September 2015].

37. Association of College and Research Libraries, Information Literacy Competency Standards for Higher Education (Chicago, Ill.: American Library Association, 2000), available online at www. ala.org/acrl/sites/ala.org.acrl/files/content/standards/standards.pdf [accessed 25 September 2015]; Association of College and Research Libraries, Framework for Information Literacy for Higher Education (Chicago, Ill.: American Library Association, 2015), available online at www.ala.org/acrl/ standards/ilframework [accessed 25 September 2015].

38. Linda Frederiksen, The Copyright Librarian: A Practical Handbook(Waltham, Mass.: Chandos Publishing, 2015). 